\title{
GIS-based comparative assessment of groundwater potential zone using MIF and AHP techniques in Cooch Behar district, West Bengal
}

\author{
Ujjal Senapati $^{1}$ iD $\cdot$ Tapan Kumar Das ${ }^{2}$
}

Received: 19 June 2021 / Accepted: 27 September 2021 / Published online: 11 February 2022

(c) The Author(s) 2022

\begin{abstract}
Global warming, change in climate and rapid growth of population have put a huge strain on the world's groundwater resources. The use of excess groundwater has created a drop in the water table. Increased use of groundwater for agriculture in agro-based areas increases the demand for groundwater. The current study has been conducted in Cooch Behar, an agrobased remote district of North Bengal in the Indian state of West Bengal, where the use of high groundwater in agriculture has reduced groundwater levels. Comparative assessment of Multi-Influencing Factor (MIF) and Analytical Hierarchy Process (AHP) techniques has been used to create a perspective mapping of groundwater potential zone for the research region. Land use and land cover (LULC), rainfall, soil texture, geomorphology, lithology, drainage density, Normalized Differential Vegetation Index (NDVI), and Topographic Wetness Index (TWI) have been used to create the map. The MIF and AHP techniques have been used for Groundwater Potential Zones (GPZ) mapping. Output GPZ has been classified into 5 classes, i.e., very poor, poor, moderate, good, and excellent. MIF technique shows that the groundwater potential classes are covering $9 \%\left(285 \mathrm{~km}^{2}\right), 21 \%\left(67 \mathrm{~km}^{2}\right), 30 \%\left(944 \mathrm{~km}^{2}\right), 27 \%\left(837 \mathrm{~km}^{2}\right)$ and $13 \%\left(410 \mathrm{~km}^{2}\right)$ of the study area, respectively, whereas the output GPZ from AHP technique shows that the groundwater potential classes are covering $8 \%\left(271 \mathrm{~km}^{2}\right), 15 \%\left(508 \mathrm{~km}^{2}\right)$, $24 \%\left(813 \mathrm{~km}^{2}\right), 33 \%\left(1118 \mathrm{~km}^{2}\right)$ and $20 \%\left(677 \mathrm{~km}^{2}\right)$, respectively. Finally, the maps have been verified using groundwater fluctuation data through Receivers Operating Characteristic curve (ROC). The MIF technique's Area Under Curve (AUC) score is $76.5 \%$, while the AHP technique reveals $88.9 \%$ accuracy. Both techniques for assessing and monitoring GPZ have been accurate and reasonable. Thus, this type of research is reliable for a more appropriate framework for swiftly analyzing groundwater recharge and directing the location of artificial recharge structures and other groundwater management operations of agricultural-based areas.
\end{abstract}

Keyword Groundwater potential zone $\cdot$ AHP $\cdot$ MIF $\cdot$ ROC $\cdot$ TWI $\cdot$ Cooch Behar

\section{Introduction}

One of the most important accumulated resources in the world is groundwater, which is unequally distributed around the world. It is the only pure natural source of drinking water, and it supports the economic life with freshwater for agricultural irrigation and industrial purposes (Senapati and Das 2021). So, groundwater plays a basic role for food

Ujjal Senapati

senapati.ujjal2012@gmail.com

1 Department of Geography, Cooch Behar Panchanan Barma University, Vivekananda Rd, Cooch Behar, West Bengal 736101, India

2 Department of Geography, Cooch Behar college, Cooch Behar, West Bengal, India security and economic development. But nowadays environmental change and quick expansion in worldwide population have made an enormous tension on the asset all around the planet. Unscientific and extreme withdrawal of groundwater has more vulnerable to depletion (Barua et al. 2021). Many countries around the world are currently facing water crisis. Groundwater is very important for the development of the local agricultural economy in many drought-prone, arid and semi-arid climatic regions. So, new international research of groundwater potentiality is being studied, and it is found that the crisis of groundwater is more severe in China, Iran, Saudi Arabia, Tunisia, Malaysia, Madagascar, Taiwan, and South Africa (Shao et al. 2020; Luo et al. 2020; Arabameri et al. 2020; Rahmati et al. 2016; Mallick et al. 2019; Zabihi et al. 2020; Manap et al. 2011; Serele et al. 2019; Yeh et al. 2016; Owolabi et al. 2020). Globally, groundwater is utilized 
in domestic uses, agricultural sector, and industrial production purposes at the Parentages of 36, 42, and 27, respectively (Taylor et al. 2012). Roughly 1.5 billion individuals are reliant upon groundwater; also 2.53 billion populations are living in extremely water-stressed regions of world (Shen et al. 2014).

Groundwater has consistently arisen as the foundation of India's agriculture and drinking water security. India's absolute annual groundwater recharge is estimated at 432 Billion Cubic Meters (BCM) (CGWB 2019). Saving a portion for normal release, the yearly extractable is 249 BCM (CGWB 2019). In India, about $62 \%$ of groundwater is used for agricultural irrigation only (CGWB 2019). Over $90 \%$ of rural and over $30 \%$ of the metropolitan populace are directly or indirectly dependent of groundwater for their work (Patra et al. 2018). In West Bengal, according to the (CGWB 2019) 2013 evaluation report, total annual replenishable resources have been surveyed as 29.33 BCM. According to survey report, net groundwater availability is $26.56 \mathrm{BCM}$, and groundwater draft for all uses is 11.84 BCM (CGWB 2019). Another report showing that total yearly groundwater accessibility in West Bengal is 22.56 and the gross draft utilized is $10.91 \mathrm{BCM}$ (Rudra et al. 2017).

Several geo-environmental factors (climate, hydrology, geology, soil, topography, drainage patterns) and several tools GIS (Geographical Information System) based on remote sensing have been utilized for the assessment of the groundwater potential zones (Bhunia 2020). Different multicriteria decision analysis (MCDA) strategies have been utilized by numerous researchers to identify groundwater potentiality such as frequency ratio (FR) (Guru et al. 2017; Doke et al. 2020), numerical modeling and decision tree (DT) (Lee and Lee 2015), and GIS-based Dempster-Shafer (DS) model (Mogaji et al. 2015). Logistic regression (LR) (Pourtaghi and Pourghasemi 2014; Nguyen et al. 2020), multivariate adaptive regression spline model (Zabihi et al. 2016), certainty factor (CF) (Razandi et al. 2015), random forest (RF) model (Naghibi et al. 2020; Chen et al. 2020), weight of evidence (WOE) (ChorbaniNejad et al. 2017), and artificial neural network (ANN) (Lee et al. 2018). Remote sensing (RS) technique and geographical information system (GIS) tools make it easy to access spatial and temporal information over a large area and by analyzing them an action can be taken quickly and timely. Thus, with the advancement of techniques, a large number of researchers are using these technologies to determine the potential groundwater availability of a particular region. This is often time-saving and cheaper compared to other expensive and efficient manpower dependent techniques. So, this technology has become quite popular for determining groundwater availability.

It is seen that a large number of researchers (Patra et al. 2018; Ferozu et al. 2018; Nithiya et al. 2019; Rajeskhar et al. 2019; Arefin 2020; Bera et al. 2020; Mukherjee and
Singh 2020; Senapati and Das 2021; Barua et al. 2021) are using GIS-based AHP techniques to determine the potential groundwater availability of a particular region. This study discusses a comparison between these two multi-criteria decision analyses (MCDA) techniques. There has been a lot of work done on groundwater potential in hard rock geological regions (Shekhar and Pandey, 2015; Parameswari and Padminni 2018; Pande et al. 2019; Das and Pal 2019; Maity and Mandal 2019; Das and Mukhopadhyay 2020; Bhattacharya et al. 2020; Maity and Mandal 2019; Das and Mukhopadhyay 2020; Bhattacharya et al. 2020; Senapati and Das 2021). In comparison, less work has been done in the field of agriculture dependent on alluvial landscape (Saha et al. 2010, 2021; Patra et al 2018; Biswas et al. 2020; Dey et al. 2021; Barua et al. 2021).

The principal objectives of the present study are to identify the groundwater potential zone in the agricultural-based Cooch Behar district of West Bengal, by using GIS-based MIF and AHP techniques. The second objective is to compare the accuracy of both technologies. Groundwater management and mapping of potential groundwater areas are essential for sustainable development of rural economic areas based on agriculture, and to understand groundwater distribution and its use of Irrigation purpose, especially in 'agricultural—predominant areas.

\section{Study area}

Cooch Behar district primarily depends on agriculture, and it is situated in foot-hills of eastern Himalayas and at the northeastern part of West Bengal, consists of twelve blocks namely, Cooch Behar-I, Cooch Behar-II, Mathabhanga-I, Mathabhanga-II, Tufanganj-I, Tufanganj-II, Haldibari, Mekhliganj, Sitai, Sitalkuchi (Fig. 1). The latitudinal and longitudinal extension of this study area are from $25^{\circ} 57^{\prime} 47^{\prime \prime} \mathrm{N}$ to $26^{\circ} 36^{\prime} 20^{\prime \prime} \mathrm{N}$ and from $88^{\circ} 47^{\prime} 44^{\prime \prime}$ $\mathrm{E}$ to $89^{\circ} 54^{\prime} 35^{\prime \prime}$ 'E, respectively. The district covers an area of $3387 \mathrm{~km}^{2}$ and the southern portion of the district is bounded by Bangladesh, while eastern part is bound by Assam, north side is bounded by Alipurduar district, and the western portion is bounded by Jalpaiguri district. The terrain of Cooch Behar is flat, with a little southern inclination. The rivers flow generally from northwest to southeast direction. The Teesta, Jaldhaka, Torsha, Kaljani, Raidak, Gadadhar, and Ghargharia are the six major rivers that run through the district. The annual rainfall received is $3021 \mathrm{~mm}$, of which $80 \%$ rainfall occurs between June and September. Summer temperature ranges from 20 to $37^{\circ} \mathrm{C}$, while winter temperature ranges from $5^{\circ}$ to $22{ }^{\circ} \mathrm{C}$. The average maximum temperature is $31^{\circ} \mathrm{C}$, while the average lowest temperature is $20^{\circ} \mathrm{C}$. Throughout the year, the air is quite humid. The district's physiography is dominated 

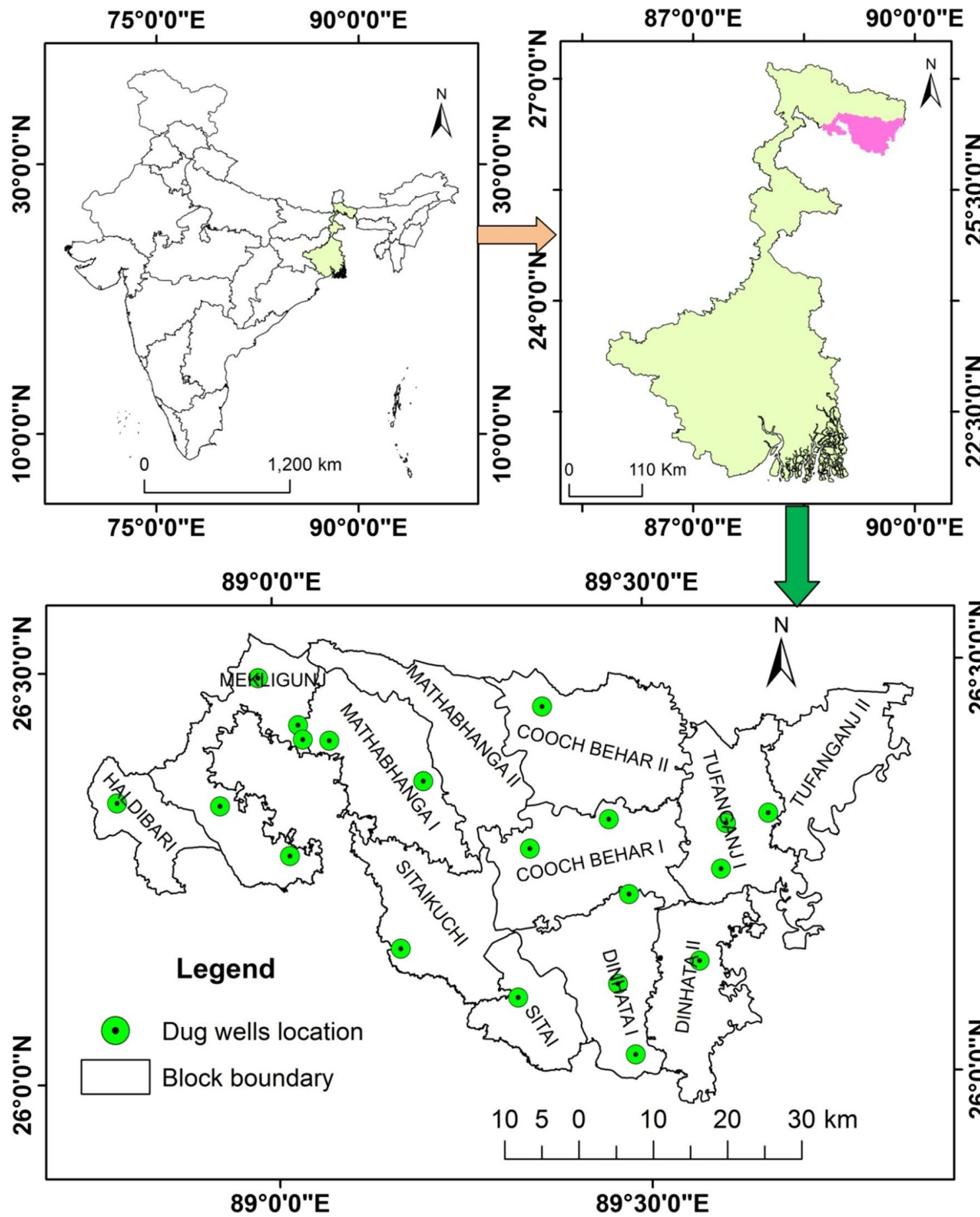

Fig. 1 Location map of the study area

by active and old alluvial flood plains; hence, the soil is created by alluvial deposits, is acidic in character and has low nitrogen content. It is friable to loam to sandy loam with a depth of 0.15 to $1 \mathrm{~m}$. As a result, about $85-90 \%$ of the population is working in agricultural activity. The main crops of this district are paddy, jute, wheat, potato, tobacco and maize.

\section{Materials and methods}

Groundwater potential zone (GWPZ) maps have been generated using various factors, i.e., land use and land cover (LULC), rainfall, soil texture, geomorphology, drainage density, lithology, normalized difference vegetation index (NDVI) and topographic wetness index (TWI). The data 
have been gathered from the many sources listed below (Table 1).

\section{Thematic layer preparation}

The LULC maps and NDVI map have been created using Landsat 8 OLI (Operational Land Imager) satellite image obtained from (United States Geological Survey) USGSEarthExplorer; then, accuracy assessment is calculated by field verification. It was pre-processed for noise and haze removal before being composited all bands. The maximum likelihood classification tool in ArcGIS 10.3 environment has been used to produce classification using the supervised classification approach. The inverse distance weighted (IDW) interpolation method is used to create the rainfall distribution map. The rainfall data have been collected from the India Meteorological Department (IMD), Pune. Using data from the SRTM-DEM, the flow direction map was created first, and then, the flow accumulation map and, lastly, the streams were created with the help of the spatial analysis tools in ArcGIS 10.3. The drainage density map is created using the line density tool. The soil map is created using the soil data gathered from the (National Bureau of Soil Survey and Land Use Planning) NBSS \& LUP. The GSI provided the lithology map, while the National Remote Sensing Centre (NRSC)-BHUVAN thematic service provided the geomorphology map. The (World Geodetic System) WGS 84 datum and (Universal Transverse Mercator) UTM zone $45 \mathrm{~N}$ projection have been used to scan and georeferenced these maps. The ArcGIS 10.3 environmental was used to digitize the data. The SRTM data were used to create a DEM with a resolution of $30 \mathrm{~m}$. TWI map has been prepared by using SRTM DEM. All the eight raster layers are scaled down to $30 \mathrm{~m} \times 30 \mathrm{~m}$ pixel size.

\section{Methodology}

The approach is used in the current research of groundwater potential zones assessment in Cooch Behar District, West Bengal, which is illustrated in Fig. 2. All eight thematic maps are re-classed in terms of weighted overlay approaches, by using the MIF and AHP two multi-criteria decision analysis (MCDA) techniques.

\section{Multi-influencing factor (MIF) technique}

There are two main parts of the MIF technique, the first part is to find out the projected score of each influencing factor based on the interrelation with other factors and second part is weighted overlay analysis. The determination of the groundwater potential zone has been influenced by eight elements. The MIF techniques are used to calculate the interrelationships between various variable. Each variable is weighted depending on its direct and indirect strength, and subclasses are assigned based on a literature evaluation (relative relationship) and autistic behavior. Both most important and small influencing factor is given a weightage of 1.0 and 0.5 , respectively (Magesh et al. 2012a,b; Senapati and Das. 2020). A component with a higher weight value has a bigger influence, while a factor with a lower weight value has a less influencing factor on the delineation of the groundwater potential zone (Table 2).
Table 1 Details of data and sources

\begin{tabular}{|c|c|c|c|}
\hline Sources & Data description & Data type & Thematic layer/uses \\
\hline \multirow[t]{3}{*}{ USGS $^{\text {a }}$ earth explorer } & LANDSAT 8 OLI $^{\mathrm{f}}(\mathrm{LC} 08$ L1TP_138 & TIFF & LULC \\
\hline & $\begin{array}{l}\text { 042_20210425_20210501_01_T1). } \\
\text { Spatial resolution } 30 \mathrm{~m}\end{array}$ & & NDVI \\
\hline & $\begin{array}{l}\text { SRTM }^{\mathrm{g}} \text { DEM }^{\mathrm{h}} \text { (n25_e088, n25_e089, } \\
\text { n26_e088, n26_e088, n26_e089). } \\
\text { Spatial resolution } 30 \mathrm{~m}\end{array}$ & TIFF & $\begin{array}{l}\text { Drainage density } \\
\text { TWI }\end{array}$ \\
\hline $\mathrm{IMD}^{\mathrm{b}}$ & Daily rainfall data of 2000 to 2017 & Point & Rainfall \\
\hline Bhuvan & Geomorphology map & Vector & Geomorphology \\
\hline $\mathrm{GSI}^{\mathrm{c}}$ & Lithology map, Scale 1:50,000 & Soft copy & Lithology \\
\hline NBSS \& LUP & Soil texture map, Scale 1:50,000 & Soft copy & Soil texture \\
\hline $\mathrm{CGWB}^{\mathrm{e}}$ & Groundwater data & Point & Validation \\
\hline
\end{tabular}

${ }^{\mathrm{a}} U S G S=$ United States Geological Survey

${ }^{\mathrm{b}} I M D=$ India Meteorological Department

${ }^{\mathrm{c}} G S I=$ Geological Survey of India

${ }^{\mathrm{d}} N B S S \& L U P=$ National Bureau of Soil Survey and Land Use Planning

${ }^{\mathrm{e}} C G W B=$ Central Ground Water Board

${ }^{\mathrm{f}} O L I=$ Operational Land Imager

${ }^{\mathrm{g}} S R T M=$ Shuttle Radar Topography Mission

${ }^{\mathrm{h}} D E M=$ Digital Elevation Model 


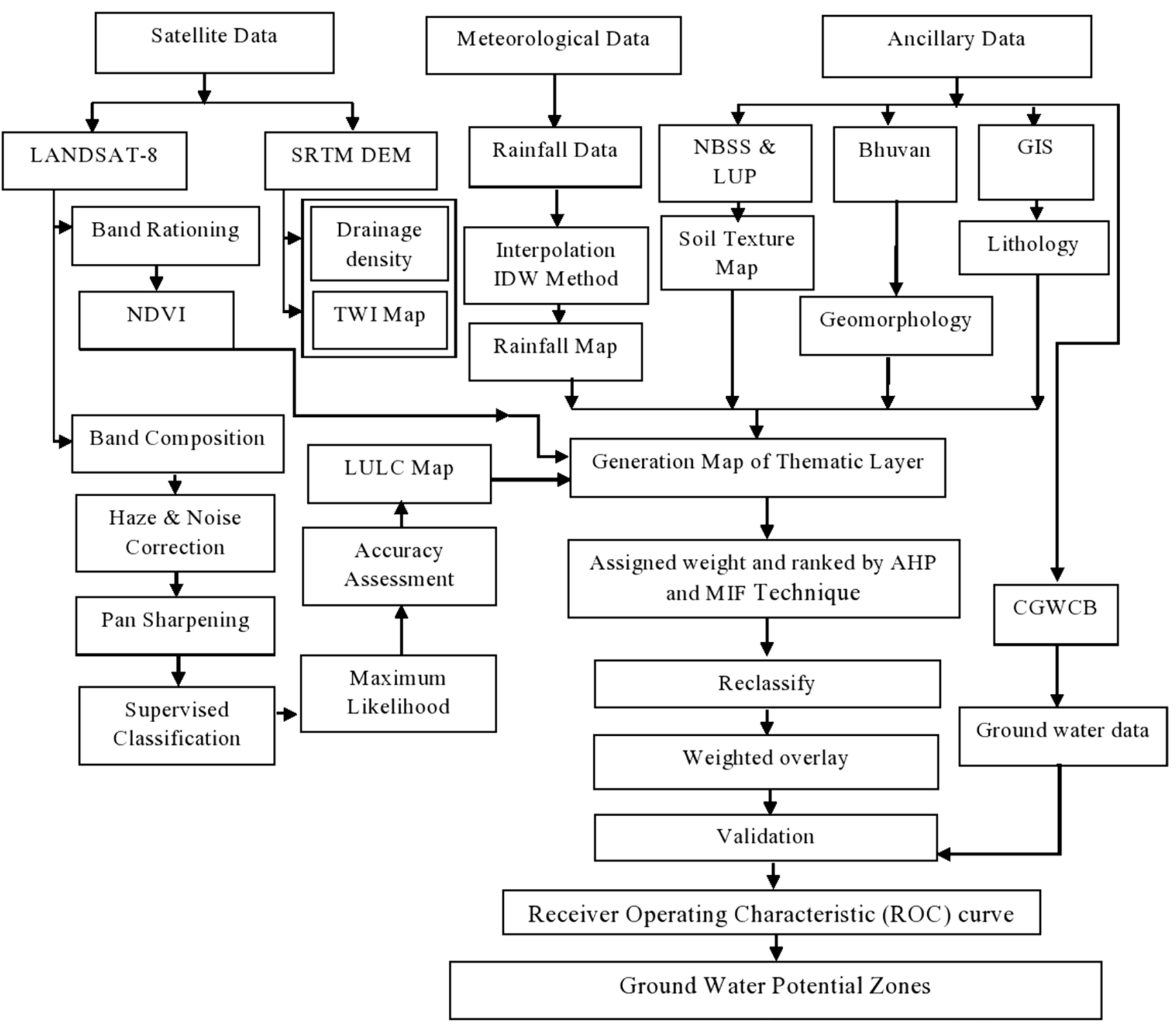

Fig. 2 Systematic flowchart for groundwater potential zones in Cooch Behar District

Following the formula, the recommended weighted for each influencing element calculated (Raju et al. 2019).

Proposed score $=\left[\frac{(X+Y)}{\sum(X+Y)}\right] \times 100$

where $\mathrm{X}$ is direct interrelationship among two factor and $Y$ is indirect interrelationship between two factors.

\section{Analytical hierarchy process (AHP) techniques}

The AHP technique is a decision-making technique, which provides qualitative and quantitative information of various criteria of a pairwise comparison approach (Saaty 1980). They are rated to 1-9 based on the important of these thematic levels and their characteristics on groundwater 
Table 2 Effect of influencing factor, relative rates and score for each potential factor (Magesh et al. 2012a,b)

\begin{tabular}{lllll}
\hline Factor & $\begin{array}{l}\text { Major effect } \\
(X)\end{array}$ & $\begin{array}{l}\text { Minor effect } \\
(Y)\end{array}$ & $\begin{array}{l}\text { Proposed relative rates } \\
(X+Y)\end{array}$ & $\begin{array}{l}\text { Proposed score of } \\
\text { each influencing } \\
\text { factor }\end{array}$ \\
\hline LULC & 3 & 2 & 5 & 16 \\
Soil texture & 1 & 1 & 2 & 6 \\
Rainfall & 5 & 1 & 5 & 16 \\
Drainage density & 4 & 0.5 & 4.5 & 14 \\
Geomorphology & 3 & 1 & 4 & 13 \\
Lithology & 2 & 1 & 3 & 9 \\
NDVI & 3 & 1 & 4 & 13 \\
TWI & 3 & 1 & 4 & 13 \\
& & & $\Sigma 31.5$ & $\Sigma 100$ \\
\hline
\end{tabular}

Table 3 Description of Saaty scales for Pairwise comparison with AHP (

\begin{tabular}{lll}
\hline Scales & Degree of preferences & Descriptions \\
\hline 1 & Equally important & The contributions of two factors are equally important \\
3 & Moderate importance & Experiences and judgment slightly tend to certain factor \\
5 & Strong importance & Experiences and judgment strongly tend to certain factor \\
7 & Very strong importance & Experiences and judgment tend to certain factor with extreme strong \\
9 & Extreme importance & There is sufficient evidence for absolutely tending to certain factor \\
$2,4,6,8$ & Intermediate values & In between two judgments \\
\hline
\end{tabular}

Source: Saaty 1990)

Table 4 Pairwise comparison matrix of groundwater potentiality in Cooch Behar District

\begin{tabular}{llllllllllll}
\hline Themes & $\begin{array}{l}\text { Assigned } \\
\text { weight }\end{array}$ & LULC & Soil & Rainfall & D.D & $\begin{array}{l}\text { Geomor- } \\
\text { phology }\end{array}$ & Lithology & NDVI & TWI & $\begin{array}{c}\text { Geometric mean } \\
\text { Normal- } \\
\text { ized } \\
\text { weight }\end{array}$ \\
\hline LULC & 7 & $7 / 7$ & $7 / 6$ & $7 / 5$ & $7 / 5$ & $7 / 4$ & $7 / 3$ & $7 / 2$ & $7 / 1$ & 1.972 & 0.212 \\
Soil & 6 & $6 / 7$ & $6 / 6$ & $6 / 5$ & $6 / 5$ & $6 / 4$ & $6 / 3$ & $6 / 2$ & $6 / 1$ & 1.690 & 0.182 \\
Rainfall & 5 & $5 / 7$ & $5 / 6$ & $5 / 5$ & $5 / 5$ & $5 / 4$ & $5 / 3$ & $5 / 2$ & $5 / 1$ & 1.409 & 0.152 \\
D.D & 5 & $5 / 7$ & $5 / 6$ & $5 / 5$ & $5 / 5$ & $5 / 4$ & $5 / 3$ & $5 / 2$ & $5 / 1$ & 1.409 & 0.152 \\
Geomorphology & 4 & $4 / 7$ & $4 / 6$ & $4 / 5$ & $4 / 5$ & $4 / 4$ & $4 / 3$ & $4 / 2$ & $4 / 1$ & 1.127 & 0.121 \\
Lithology & 3 & $3 / 7$ & $3 / 6$ & $3 / 5$ & $3 / 5$ & $3 / 4$ & $3 / 3$ & $3 / 2$ & $3 / 1$ & 0.845 & 0.091 \\
NDVI & 2 & $2 / 7$ & $2 / 6$ & $2 / 5$ & $2 / 5$ & $2 / 4$ & $2 / 3$ & $2 / 2$ & $2 / 1$ & 0.563 & 0.061 \\
TWI & 1 & $1 / 7$ & $1 / 6$ & $1 / 5$ & $1 / 5$ & $1 / 4$ & $1 / 3$ & $1 / 2$ & $1 / 1$ & 0.282 & 0.030 \\
\hline
\end{tabular}

Table 5 Random index (RI) value

\begin{tabular}{lllllllllll}
\hline $\mathrm{n}$ & 1 & 2 & 3 & 4 & 5 & 6 & 7 & 8 & 9 & 10 \\
\hline RCI value & 0 & 0 & 0.58 & 0.9 & 1.12 & 1.24 & 1.32 & 1.41 & 1.45 & 149 \\
\hline
\end{tabular}

Source: Saaty 1990) potentiality. A higher score indicates greater impact on groundwater potentiality. The score is diagonally arranged in a comparison matrix, which has an equal number of columns and rows. The value " 1 " is obliquely inserted in the matrix, running from the middle to the corner. Each criterion is scored against every other criterion by assigning a relative dominating scale between 1 and 9 for the building of a pairwise comparison matrix (Table 3), and preference criteria are scored from 1 to 9 depending on their relative relevance. Here, pairwise comparison matrix of groundwater potentiality in Cooch Behar district is shown in (Table 4). The consistency ratio (CR) is determined by using the random 
index scale (Saaty 1980) (Table 5) and the acquired Eigenvalue from the comparison matrix. The consistency value for the matrix is acceptable if the CR value is less than 1.0 (Senapati et al. 2021).

Consistency ratio $(\mathrm{CR})=\frac{\text { Consistency Index }(\mathrm{C} \cdot \mathrm{I})}{\text { Random Consistency Index }(\mathrm{RCI})}$

where

Consistency Index $(\mathrm{CI})=\left(\lambda_{\max }-n\right) /(n-1)$

where $\lambda_{\max }$ is the principal Eigenvalue and $\mathrm{n}$ is the number of factors.

In this study, pairwise normalized matrix determined the parameters weight is shown in Table 6 and their sub-criteria weight of both AHP and MIF technique is shown in Table 7. Here, calculated principal Eigenvalue $(\lambda)=\left(\lambda_{\max }=64 / 8\right)$ is 8 , consistency index $(\mathrm{CI})=\left\{\left(\lambda_{-} \max -n\right) /(n-1)\right\}$ IS 0 , random consistency index (RCI) is 1.41 and consistency ratio $(\mathrm{CR})=(\mathrm{CI} / \mathrm{RCI})$ is 0 .

\section{Result and discussion}

\section{Land use and Land cover (LULC) and groundwater potentiality}

LULC are important elements that control soil moisture, penetration, surface runoff rate which directly regulates groundwater recharge (Yeh et al. 2016; Senapati and Das. 2021). This type of LULC manages the storage of groundwater through a complex geological process on the ground surface. In these alluvial aquifer regions, LULC is a leading controlling aspect to identify groundwater availability. Dense vegetation, sparse vegetation, cultivated land, current agricultural fallow, settlement, river and water bodies, and sand bar are the seven types of LULC patterns seen in the research region (Fig. 3). Most of the region falls under the category of agricultural area. The cultivated land covers $48 \%$, current agricultural fallow covers $31 \%$, settlement
$6 \%$, water bodies $5 \%$, sand bar $4.5 \%$, dense vegetation $3 \%$, sparse vegetation $2.5 \%$ of the land area. On the basis of 156 random sample points and ground truth information, accurate evaluation of the LULC map has been measured the overall accuracy was found to be $91 \%$ and the kappa coefficient calculated is 0.78775 . Area of agricultural land, water bodies and natural vegetation are suitable for groundwater recharge, through water infiltration (Thapa et al. 2017). Fields of natural vegetation have been given moderately high weight because the shots gradually decrease the surface flow and increase the penetration rate (Bhattacharya et al. 2020; Senapati and Das 2021). Agricultural fields offer a lot of groundwater recharge capacity (Biswas et al. 2020) and low groundwater recharge due to low infiltration rate in settlement areas.

\section{Soil texture and groundwater potentiality}

The soils texture a crucial role in controlling the groundwater potentiality zones because soil texture directly regulates the porosity, adhesion and consistency (Patra et al., 2018; Senapati and Das 2021). The soil texture map was collected from National Bureau of Soil Survey and Land Use Planning (NBSS \& LUP). The infiltration and retention rate of groundwater are controlled by the soil type, which influences permeability. The finer the soil texture, the lower the infiltration capacity and as a result the less groundwater will be recharged; conversely, the coarser the soil texture, the higher the research region is divided into five different types: coarse loamy-fine loamy soil, coarse loamy soil, fine loamy soil, fine loamy-coarse loamy soil and fine-coarse loamy soil, which is considered $440 \mathrm{~km}^{2}, 813 \mathrm{~km}^{2}, 373 \mathrm{~km}^{2}, 1084 \mathrm{~km}^{2}$, and $677 \mathrm{~km}^{2}$. These categories covered $13 \%, 24 \%, 11 \%, 32 \%$ and $20 \%$ of total area, respectively (Fig. 4).

\section{Rainfall and groundwater potentiality}

Rainfall is the major primary source of groundwater recharge. It has an impact on the rate of infiltration and surface runoff depending on the rainfall volume

Table 6 Pairwise normalized matrix of groundwater potentiality in Cooch Behar District

\begin{tabular}{lllllllllll}
\hline Themes & LULC & Soil & Rainfall & D.D & Geomorphology & Lithology & NDVI & TWI & Weighted sum & Row average \\
\hline LULC & 0.212 & 0.212 & 0.212 & 0.212 & 0.212 & 0.212 & 0.212 & 0.212 & 1.697 & 0.212 \\
Soil & 0.182 & 0.182 & 0.182 & 0.182 & 0.182 & 0.182 & 0.182 & 0.182 & 1.455 & 0.182 \\
Rainfall & 0.152 & 0.152 & 0.152 & 0.152 & 0.152 & 0.152 & 0.152 & 0.152 & 1.212 & 0.152 \\
D.D & 0.152 & 0.152 & 0.152 & 0.152 & 0.152 & 0.152 & 0.152 & 0.152 & 1.212 & 0.152 \\
Geomorphology & 0.121 & 0.121 & 0.121 & 0.121 & 0.121 & 0.121 & 0.121 & 0.121 & 0.970 & 0.121 \\
Lithology & 0.091 & 0.091 & 0.091 & 0.091 & 0.091 & 0.091 & 0.091 & 0.091 & 0.727 & 0.091 \\
NDVI & 0.061 & 0.061 & 0.061 & 0.061 & 0.061 & 0.061 & 0.061 & 0.061 & 0.485 & 0.061 \\
TWI & 0.030 & 0.030 & 0.030 & 0.030 & 0.030 & 0.030 & 0.030 & 0.030 & 0.242 & 0.030 \\
\hline
\end{tabular}


Table 7 Normalized weight of subclasses

\begin{tabular}{|c|c|c|c|}
\hline Factor & Domain of effect & AHP weight & MIF weight \\
\hline \multirow[t]{7}{*}{ LULC } & Settlement & 0.035 & 5 \\
\hline & Sand bar & 0.051 & 13 \\
\hline & Current agricultural fallow & 0.078 & 9 \\
\hline & Cultivation land & 0.123 & 11 \\
\hline & Water bodies & 0.198 & 16 \\
\hline & Sparse vegetation & 0.198 & 14 \\
\hline & Dense vegetation & 0.316 & 14 \\
\hline \multirow[t]{5}{*}{ Soil texture } & Fine-coarse loamy & 0.061 & 2 \\
\hline & Fine loamy-coarse loamy & 0.097 & 3 \\
\hline & Fine loamy & 0.159 & 5 \\
\hline & Coarse loamy & 0.262 & 6 \\
\hline & coarse loamy-fine loamy & 0.148 & 4 \\
\hline \multirow[t]{5}{*}{ Rainfall } & $2545-2684 \mathrm{~mm}$. (very poor) & 0.061 & 10 \\
\hline & 2684-2845 mm. (poor) & 0.097 & 12 \\
\hline & 2845-2969 mm. (moderate) & 0.159 & 14 \\
\hline & 2969-3043 mm. (good) & 0.262 & 15 \\
\hline & 3043-3178 mm. (very good) & 0.061 & 16 \\
\hline \multirow[t]{5}{*}{ Drainage density } & $0.0241-0.961$ (very poor) & 0.061 & 8 \\
\hline & $0.962-1.4$ (poor) & 0.097 & 10 \\
\hline & $1.41-1.81$ (moderate) & 0.149 & 12 \\
\hline & $1.81-2.36$ (good) & 0.329 & 14 \\
\hline & $2.37-5.58$ (very good) & 0.361 & 14 \\
\hline \multirow[t]{4}{*}{ Geomorphology } & fluvial origin-younger alluvial plain & 0.277 & 11 \\
\hline & fluvial origin active flood plains & 0.467 & 13 \\
\hline & fluvial origin-older flood plain & 0.160 & 9 \\
\hline & fluvial origin-Piedmont alluvial plain & 0.095 & 8 \\
\hline \multirow[t]{4}{*}{ Lithology } & $\begin{array}{l}\text { Light gray silty loams underlain by unaltered multiple } \\
\text { sequence of fine sand, silt and clay with bog clay }\end{array}$ & 0.160 & 7 \\
\hline & Alternate layers of sand silt and clay & 0.095 & 6 \\
\hline & Gravel, coarse to fine sand, silt and clay & 0.277 & 8 \\
\hline & Very fine sand, silt and clay & 0.467 & 9 \\
\hline \multirow[t]{5}{*}{ NDVI } & $(-0.11-0.00)$ Water bodies (No vegetation) & 0.512 & 13 \\
\hline & $(0.00-0.11)$ No vegetation & 0.033 & 7 \\
\hline & $(0.12-0.15)$ shrubs and grassland & 0.063 & 9 \\
\hline & $(0.16-0.21)$ moderately healthy vegetation & 0.128 & 11 \\
\hline & $(0.22-0.44)$ healthy vegetation & 0.261 & 13 \\
\hline \multirow[t]{5}{*}{ TWI } & $2.43-7.78$ (very poor) & 0.033 & 9 \\
\hline & $7.78-10.33$ (poor) & 0.063 & 10 \\
\hline & 10.33-12.27 (moderate) & 0.128 & 11 \\
\hline & $12.27-14.67$ (good) & 0.261 & 12 \\
\hline & $14.67-22.19$ (very good) & 0.512 & 13 \\
\hline
\end{tabular}

duration, and intensity of the rain. Long-term low precipitation influences high surface runoff and low penetration. Groundwater recharging is also influenced by the yearly average rainfall. Higher rainfall suggests a higher groundwater potential, whereas lesser rainfall suggests a low groundwater potential. The rainfall variety in the study area varies from $2.850 \mathrm{~mm}$ yearly, which suggests a warm and temperature climate with high rainfall during the monsoons. The IDW method of spatial interpolation in the ArcGIS platform was used to create a thematic map of rainfall data collected from IDM, Pune of seven weather station: Pundibari, Cooch Behar, Haldibari, Dinhata, Mekhliganj, Tufanganj, and Mathabhanga. On the basis of the rainfall received, the research region is divided into five rainy zones, namely $8 \%$ of the total area falls into the class of very poor. $6 \%$ of the total area falls 
Fig. 3 Land use and land cover map of Cooch Behar district
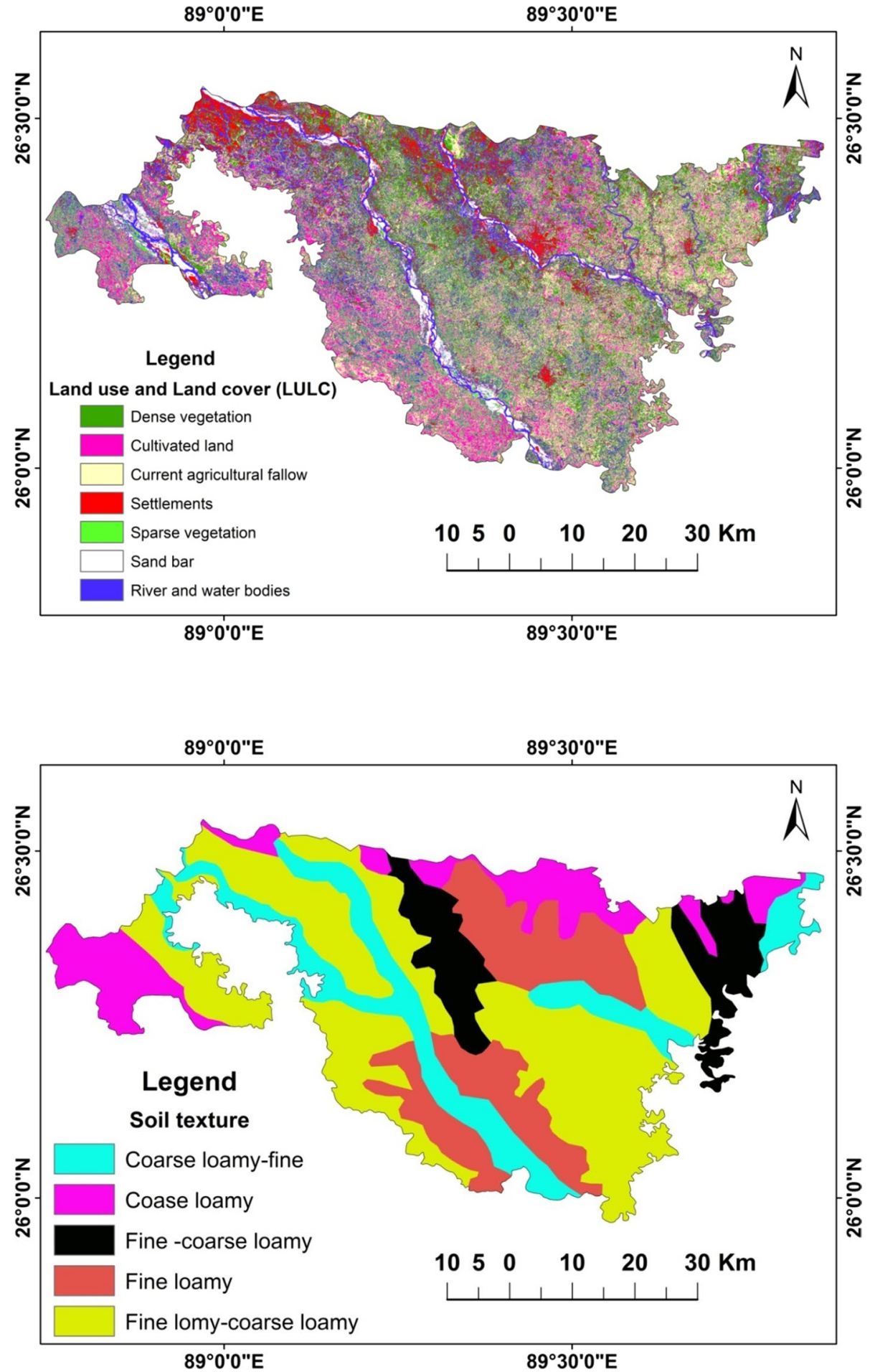

Fig. 4 Soil texture map of Cooch Behar district into the class of poor. $32 \%$ of the total area falls into the class of moderate. $30 \%$ of the total area falls into the class of good. $24 \%$ of the total area falls good (Fig. 5). Heavy rainfall was recorded in the northeastern region. Greater weight is applied to higher rainfall zones for determining groundwater zones and vice versa.

\section{Drainage density and groundwater potentiality}

Drainage density is a key indicator of infiltration rate. Drainage density is inversely proportional to permeability. Higher drainage density denotes higher surface runoff as well as less water infiltration, implying lower groundwater 
Fig. 5 Rainfall map of Cooch Behar district
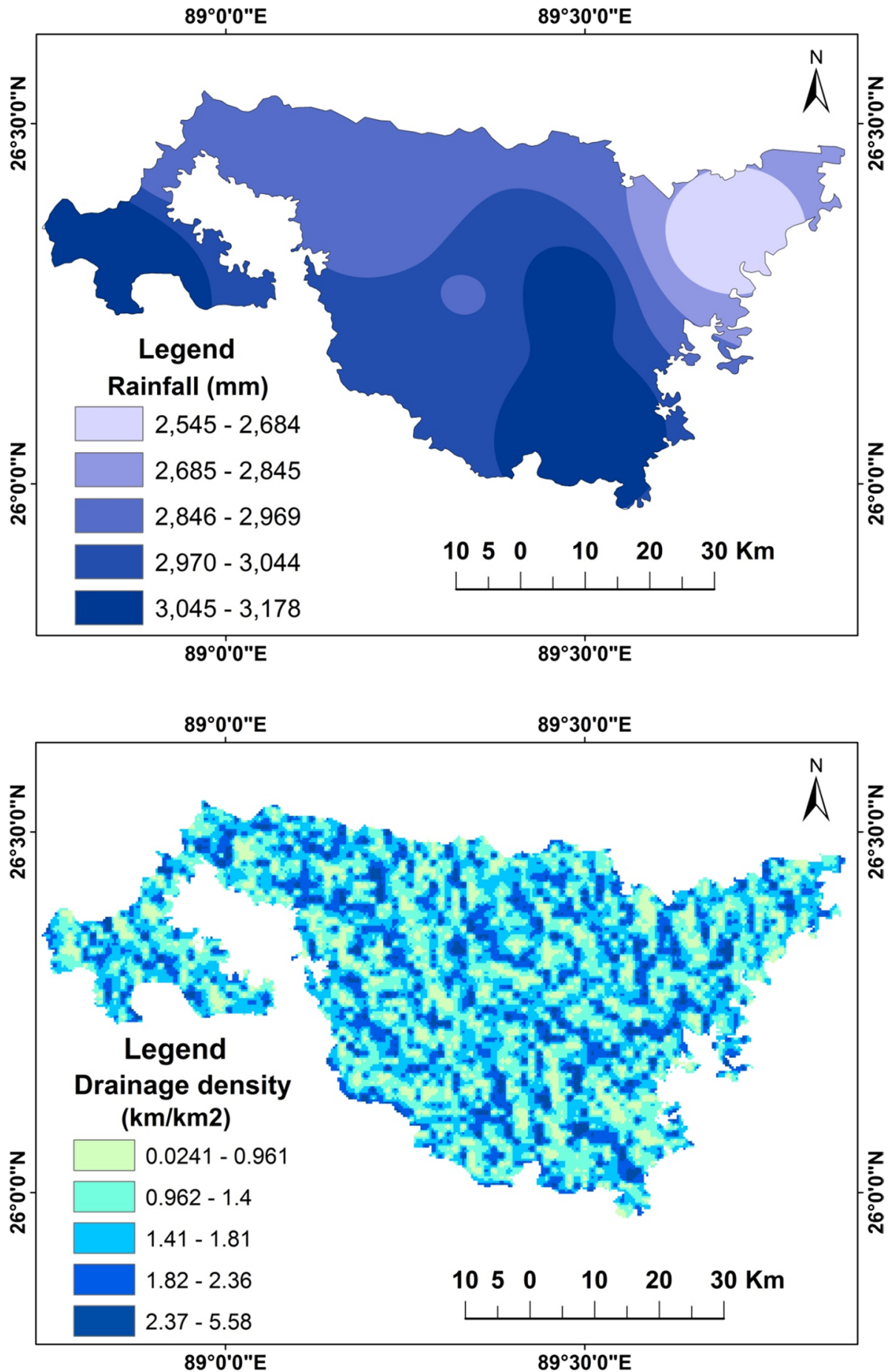

Fig. 6 Drainage density map of Cooch Behar district this area. On the basis of their drainage density values, the research areas drainage density $\left(\mathrm{km} / \mathrm{km}^{2}\right)$ has been divided into five classes (Fig. 6). The areas classified as very poor (0.0241-0.961), indicating 14\% area, poor (0.961-1.40) represent $33 \%$ area, moderate (1.41-1.81) represent 37\% area, good (1.81-2.36) represent $14 \%$ area, and very good $2.36-5.58$ ) account $2 \%$ of the overall study area. 


\section{Geomorphology and groundwater potentiality}

A basins hydrological behavior is influenced to a large extent by its geomorphological characteristics. Geomorphology refers to an areas landform and is one of the most important factors in determining the groundwater potentiality one. The research areas geomorphology is characterized by fluvial activities; it has a high potential for groundwater recharge. The following geomorphic landforms were identified in the study area and their percentage coverage such as fluvial origin-younger alluvial plains have been found among almost every segment, $51 \%$ of the study area; fluvial origin order flood plains have been found in the southern part, $28 \%$ of the study area and fluvial origin-Piedmont alluvial plain, which is observed in the nethermost section of the research region, account for $5 \%$ of the total area (Fig. 7). The high weight is initially allocated to the fluvial origin active flood plains because it is next to the river, so it has a lot of potentials to recharge while piedmont alluvial plains have a low potential for recharge due to heavy runoff.

\section{Lithology and groundwater potentiality}

The lithological characteristic is required for assessing groundwater porosity and movement. Groundwater recharge and development are influenced by permeability and porosity (Akinlaluet all. 2017). Surface lithology influences soil conditions, which are influenced by the structure, adhesion, porosity, and consistency of soil features (Senapati and Das 2021). The study area contained four types of lithological units: very fine sand, silt, and clay, which consist $24 \%$ of the total area, gravel, coarse to fine sand, silt and clay, which consist $0.3 \%$ of the total area, alternate layers of sand, silt, and clay which consist $46.7 \%$ of the total area and light gray silty loams underlain by unaltered multiple sequence of fine sand, silt and clay consist $29 \%$ of the whole area (Fig. 8). Very fine sand, silt and clay are assigned a higher weight because it is observed along the stream channel in our study area. Gravel, coarse to fine sand, silt and clay are also assigned a high weight in comparison to light gray silty loams underlain by an unaltered multiple sequence of fine sand and clay with bog clay, which has a low infiltration rate (Shekar et al. 2015).

\section{NDVI and groundwater potentiality}

NDVI is extensively used indicators for monitoring vegetation dynamic at regional and global scales. Tucker (1979) created this indicator, which ranges from -1 to 1 , with values less than 0 indicating no vegetation cover and greater than 0 denote available vegetation cover. The NDVI was computed using the formula given as follows:

$\mathrm{NDVI}=(\mathrm{NIR}$ band $-\mathrm{RED}$ band $) /(\mathrm{NIR}$ band + RED band $)$

where NIR stands for near-infrared band $(0.77-0.90 \mu \mathrm{m}$ and RED stands for visible red band $(0.630-0.680 \mu \mathrm{m})$. The presence of healthy and vegetation in a given area appears to be linked to adequate groundwater recharge. As a result, the greater the value the more weight is awarded, whereas sparse vegetation, shrubs and grassland are given a moderate amount of weight. Our study areas NDVI has been
Fig. 7 Geomorphology map of Cooch Behar district

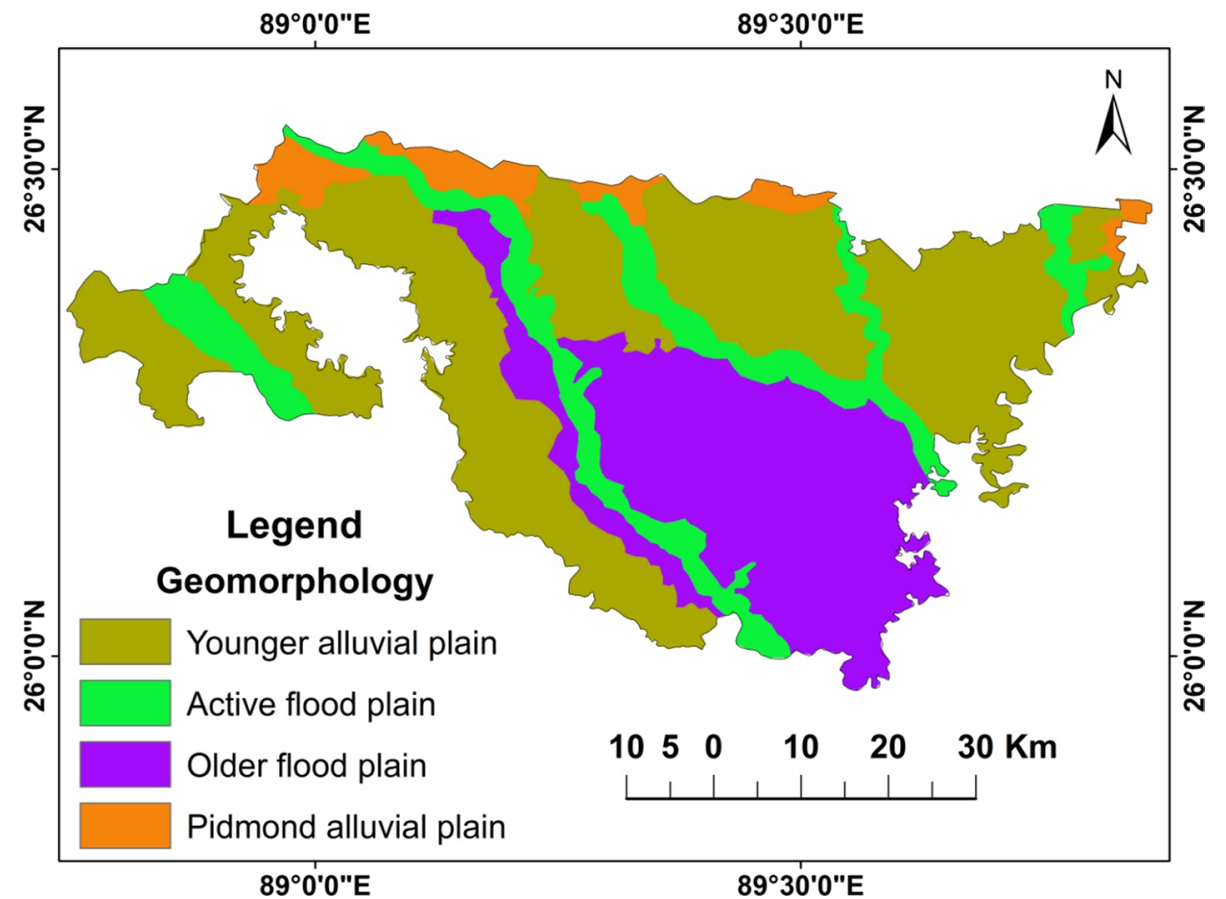


Fig. 8 Lithology map of Cooch Behar district
Fig. 9 NDVI map of Cooch Behar district
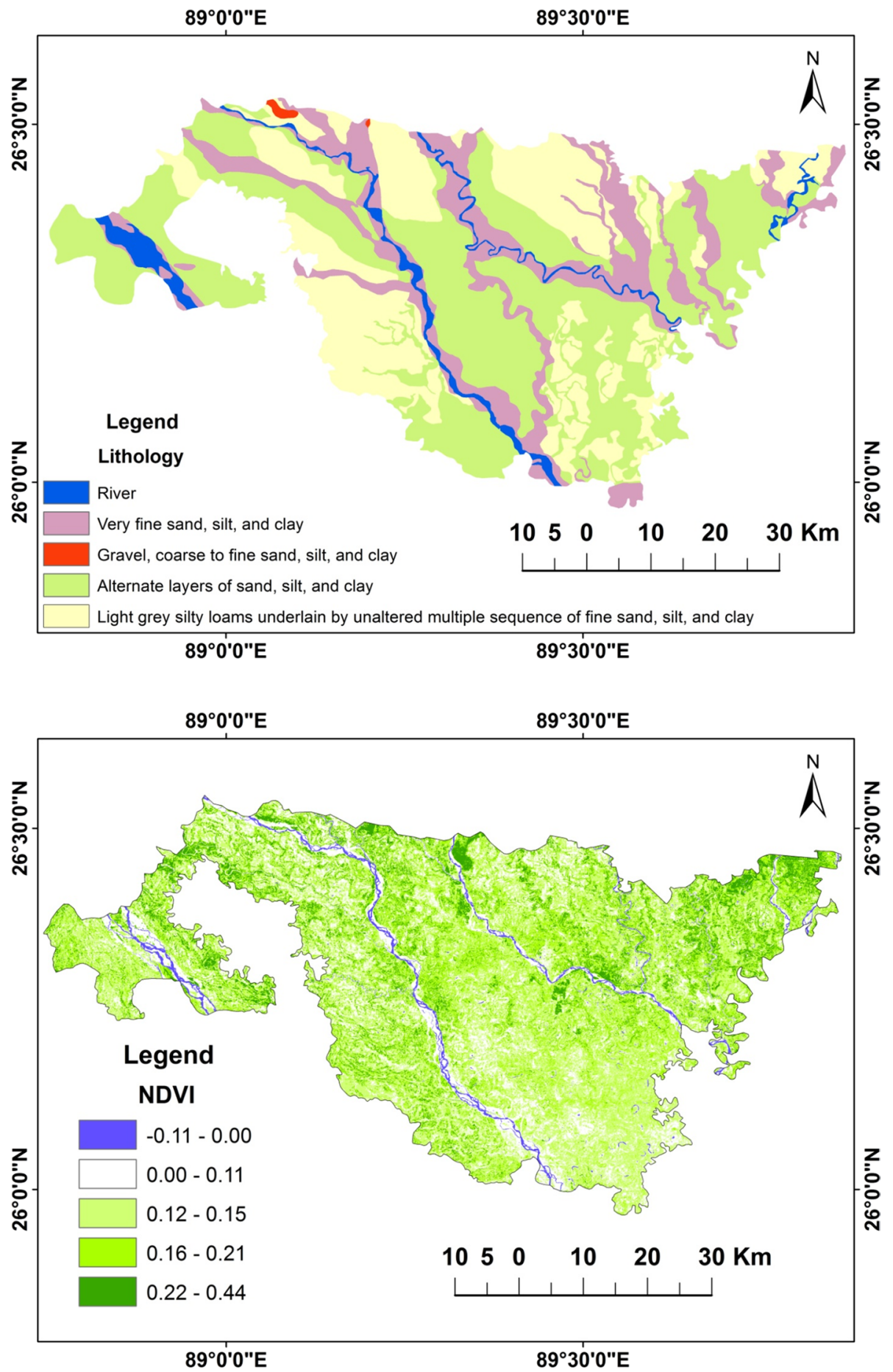

grouped into five categories in the thematic mapping, such as no vegetation are $(0-0.11)$, which occupied $3 \%$ area. Water bodies $(-0.11-0.00)$, which occupied $3 \%$ of the total area, Shrubs and grassland $(-0.12-0.15)$, which occupied $14 \%$ of the total surface area, moderately healthy vegetation $(-0.16-0.21)$, which occupied $36 \%$ of the total area and Healthy vegetation $(-0.22-0.44)$, which occupied $44 \%$ of the total area (Fig. 9).

\section{TWI and groundwater potentiality}

Topographic wetness index (TWI) is used to quantify topographic control on hydrological processes and indicates the potential groundwater infiltration induced by the impacts of topographic. So, TWI is an important parameter to determination groundwater potentiality zone. In a regional topography, TWI represents the geographical distribution of wetness 
conditions. It controls the water inclination to accumulate as well as the water tendency tom flow down the slope under gravity.

TWI is calculated as follows:

$\mathrm{TWI}=\operatorname{In}(\mathrm{As} / \tan )$

where As is the particular river basin and $\tan \beta$ is the local slope angle of the particular grid.

The TWI value in our study area ranges from 2.43 to 22.19. The values were divided into five groups. These are following 2.43-7.78 occupied 7\% of the total area and were classified as extremely poor, 7.78-10.33 occupies $20 \%$ of the total area and was classified as poor, 10.33-12.27 occupied $23 \%$ of the entire area and was classified as moderate, 12.27-14.67 occupied $20 \%$ of the total area good and 14.67-22.19 occupied $29 \%$ of the entire area classified as excellent (Fig. 10). High flow reserves and linear slope areas have a higher TWI value, where steep slopes and higher drainage indicate lower TWI values. For a high TWI value, a high weight has been allocated and vice versa.

\section{Groundwater potential zone (GPZ) map}

Groundwater potentiality zones have been identified for the research region using a multi-influencing AHP and MIF technique through GIS-weighted overlay analysis. The weighs of eight thematic layers have been added together to create the final groundwater potential map.

The field of investigation revealed five separate classification zones based on the outcome map: very poor, poor, moderate, good, and excellent. In the basis of AHP technique the geographically area extension of $271 \mathrm{~km}^{2}, 508 \mathrm{~km}^{2}$, $813 \mathrm{~km}^{2}, 1118 \mathrm{~km}^{2}$ and $677 \mathrm{~km}^{2}$ respectively (Fig. 11). $20 \%$ of the groundwater potential in the research region is excellent, $33 \%$ is good, $24 \%$ is moderate, $15 \%$ is poor and $8 \%$ is very poor. On the other hand, MIF technique shows that the very poor GWPZ covers an area of $285 \mathrm{~km}^{2}$ which represents $9 \%$ of the total area. Poor GPZ cover $671 \mathrm{~km}^{2}$ (21\%), moderate GPZ cover $944 \mathrm{~km}^{2}$ (30\%) area, good GPZ cover $837 \mathrm{~km}^{2}(27 \%)$, and excellent GPZ cover $410 \mathrm{~km}^{2}$ (13\%) area (Fig. 12) (Table 8). The results demonstrate that a good and excellent GPZ is concentrated in the southwestern and northeastern sections of the study area particularly in Haldibari, Mekhliganj, Sitai, and Sitalkuchi blocks. High intensity of rainfall, the fluvial origin active flood plains, very fine sand silt clay, extensive agricultural land, and coarse loamy-fine textured influence groundwater recharge. Cooch Behar-II, Tufanganj-II, Dinhata-I, Dinhata-II, and Mathabhanga-I blocks are under moderate GPZ. Cooch Behar-I, Mathabhanga-I, and Tufanganj-I blocks are under low GPZ. The groundwater potential zone map allows us to have a good awareness of a region groundwater situation in order to prepare for long-term groundwater extraction, suitable planning and management for suitable development.

\section{Validation}

Validation is important in scientific study. The final groundwater potential zone (GWPZ) is validated using 45 real groundwater data samples acquired from the CGWB, and the model is validated using a receiver operating
Fig. 10 TWI map of Cooch Behar district

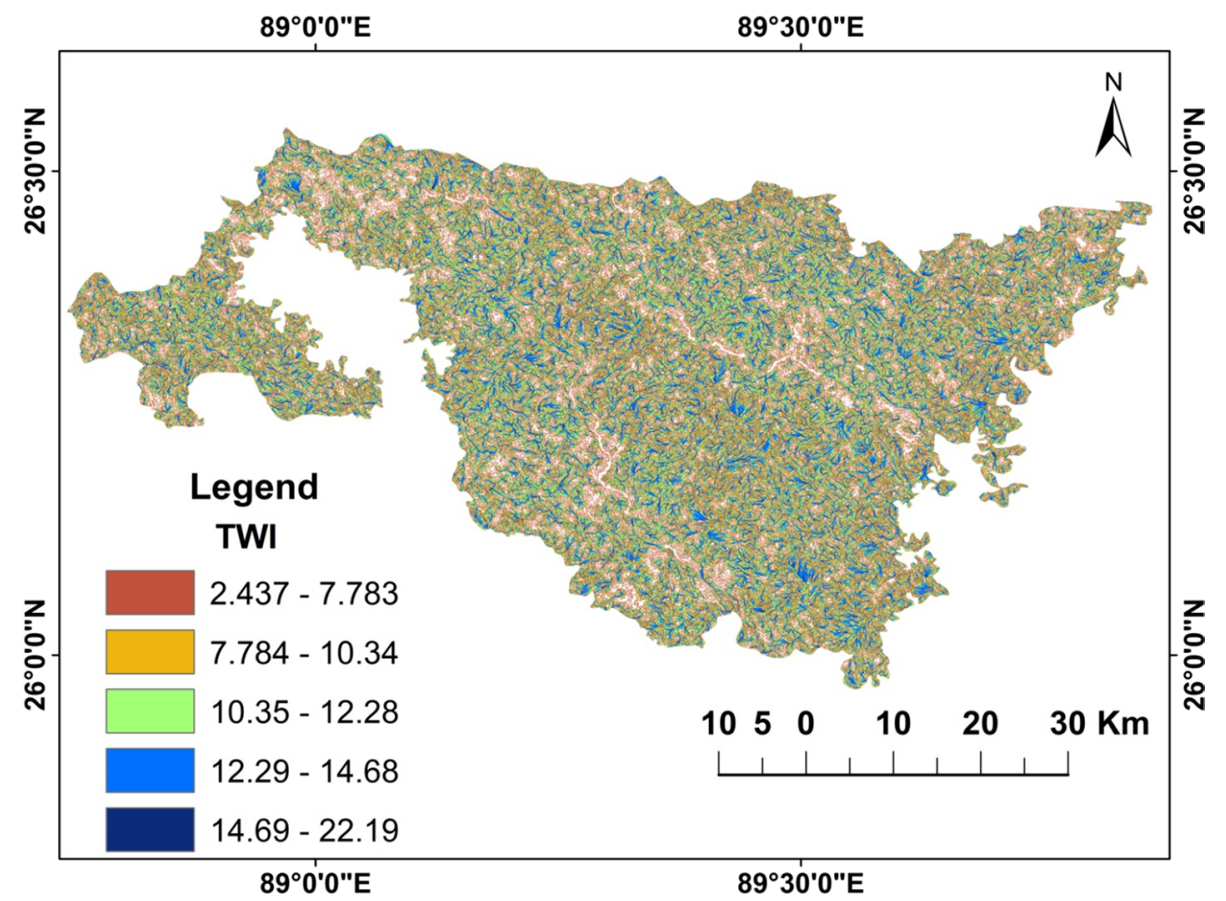


Fig. 11 Groundwater potentiality zones map using MIF Technique

Fig. 12 Groundwater potentiality zones map using AHP Technique

Table 8 Area and $\%$ of different groundwater potential zone in MIF and AHP technique
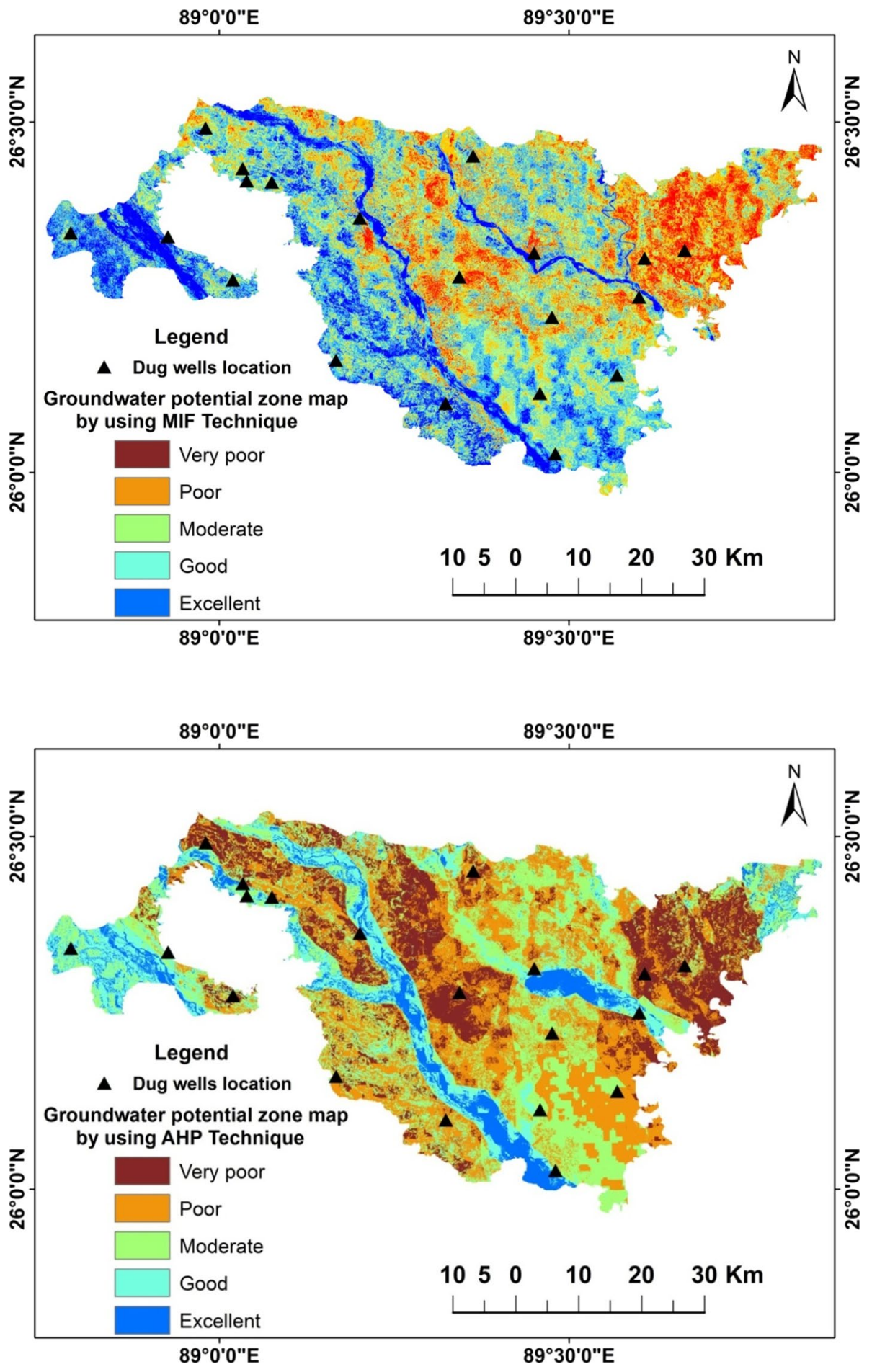

\begin{tabular}{llcrccr}
\hline GWPZ & MIF-area & \% of the area & MIF-value & AHP-area & \% of the area & AHP-value \\
\hline Very poor & 285 & 9 & $769-977$ & 271 & 8 & $(74.75-143.84)$ \\
Poor & 671 & 21 & $977-1034$ & 508 & 15 & $(143.84-177.39)$ \\
Moderate & 944 & 30 & $1034-1083$ & 813 & 24 & $(177.39-212.92)$ \\
Good & 837 & 27 & $1083-1138$ & 1118 & 33 & $(212.92-258.32)$ \\
Excellent & 410 & 13 & $1138-1332$ & 677 & 20 & $(258.32-578.08)$ \\
\hline
\end{tabular}


characteristics (ROC) curve. To determine map accuracy, the ROC curve was used as a mathematical approach by using SPSS (Statistical Package for the Social Sciences) statistical software. The cumulative percentage of the area (on the $\mathrm{x}$-axis) and the cumulative percentage of the number of wells (on the $y$-axis) were used to create ROC curves. The area under the curve (AUC) was determined to assess the capacity to forecast the occurrence or nonoccurrence of pre-defined "events." The prediction rate is depicted as a blue line in a visual depiction (Fig. 13a and $b$ ). The forecasting percentage was studied using the area under the curve (AUC) scale, which ranged from 0.5 to 1.0. The AUC value is classified in the following sequence: poor, average, good, very good, and excellent with the range from "0.5-0.6," "0.6-0.8," "0.8-0.9" and "0.9-1.0," respectively (Senapati and Das 2019; Arabameri et al. 2018; Senapati and Das 2021). The MIF technique delivers $76.5 \%$ accuracy denoting that it is a good predicator, whereas the AHP technique delivers $88.9 \%$ accuracy, a very good predicator model to delineate the groundwater potential zone (GPZ). Although, both techniques for measuring groundwater Potential Zone in the Cooch Behar district were quite accurate and reasonable. Based on the ROC-AUC curve, the AHP method yielded substantially more accurate findings than the MIF technique. The categorization criteria, mean rating score, and

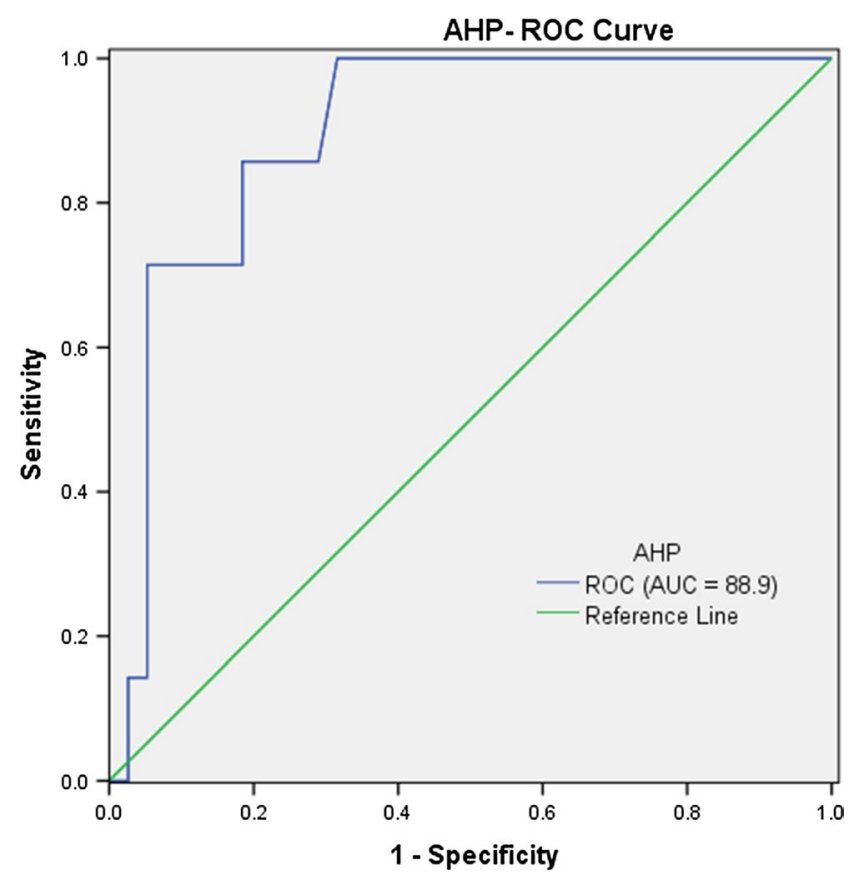

(a) ROC curve for groundwater potentiality zones map using AHP Technique weights allocated to the thematic layers all have depended on the accuracy of the techniques.

\section{Conclusion}

GIS based two MCDM methods have been using, namely AHP and MIF Technique the current study was conducted on the groundwater potential zone in the agriculture-dominated Cooch Behar district. Cooch Behar-I and II, Dinhata-I and II, Mathabhanga-I and II, Tufanganj-I and II, Haldibari, Mekhliganj, Sitai, Sitalkuchi are the twelve blocks of Cooch Behar district studied. The groundwater potential map was created using 8 geo-environmental parameters. The factors that were considered include LULC, rainfall, soil texture, geomorphology, lithology, drainage density, NDVI, and TWI. The research region was categorized into five zones based on the output map: very poor, poor, moderate, good, and excellent. The GPZ has been evaluated as excellent $(20 \%)$, good $(33 \%)$, moderate $(24 \%)$, poor $(15 \%)$, and very poor (8\%) using the AHP technique. According to the MIF technique, $13 \%$ of the research area has excellent groundwater potential, while the remaining $27 \%$ has good groundwater potential. The rest of the area has moderate $(30 \%)$, poor $(21 \%)$, and very poor $(20 \%)$ potential. The results have been validated with the mean annual groundwater fluctuation data

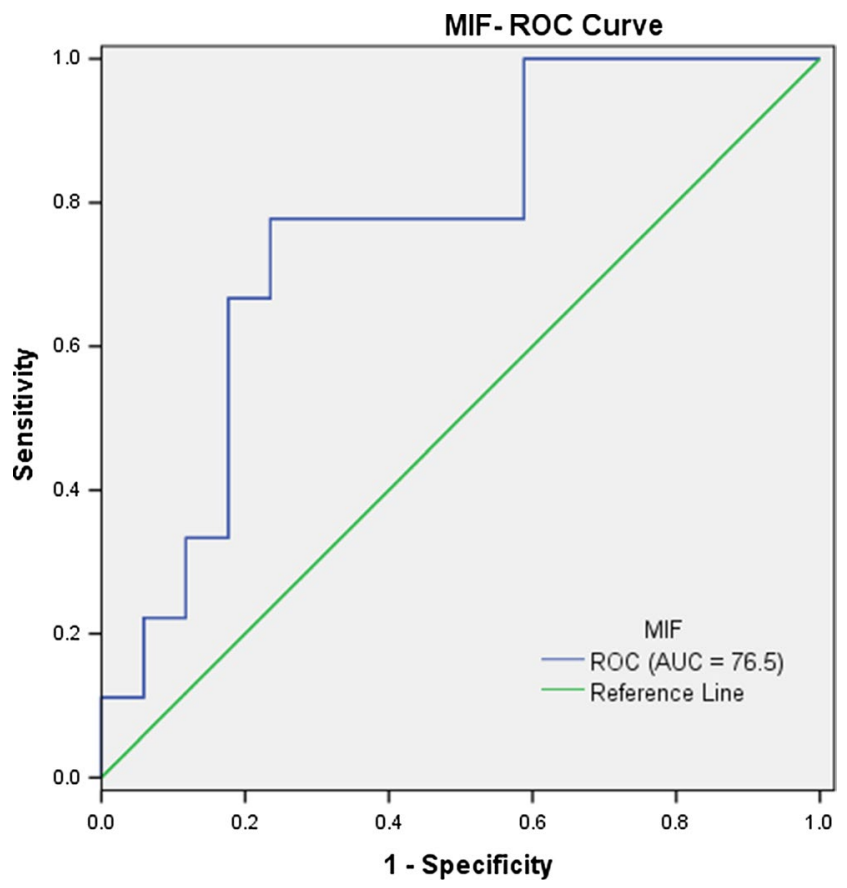

(b) ROC curve for groundwater potentiality zones map using MIF Technique

Fig. 13 a ROC curve for groundwater potentiality zones map using AHP Technique. b ROC curve for groundwater potentiality zones map using MIF Technique 
of 45 dug wells. While the accuracy of the GPZ generated by both MCDM methods was satisfactory, the validation phase indicates that the AHP approach produced far more accurate results compared to the MIF method (AHP accuracy: $88.9 \%$ compared to MIF accuracy: $76.5 \%$ ) in the study region because the AHP technique considers the preference of the factors as well as interrelationship among themselves and then builds a pairwise comparison matrix and assesses the consistency ratio but the MIF technique is more subjective and highly dependent on the expert's knowledge/skills in the research field. This agrees with previous research (Zghibi et al. 2020; Abijith et al. 2020).

Overall, the validation results raise confidence in the used technique as a helpful framework for assessing groundwater recharge quickly and informing the placement of artificial recharge structures and other groundwater management activities. In India, groundwater management and usage are seen as a state problem; therefore, any groundwater regulation or law is enacted at the state level. We explain the results of our modeling more holistically at the macrolevel, the suitable suggestions we can offer are as follows: A state agency also monitors irrigated regions using satellite imagery and constructed certain ground monitoring stations with modern smart automated reading meters, allowing realtime monitoring of groundwater abstraction in agricultural fields, in order to detect any unlawful abstraction. Farmers' groups can also restrict groundwater abstraction by providing appropriate training. We suggest that boosting perhectare revenue through increasing production of highervalue crops may help to improve groundwater management and sustainability. Farmers can build their own irrigation system by conserving surface rainwater on their own land as well as improve groundwater sustainability by acting as a groundwater recharge structure. Above all, the sustainable development of the overall groundwater is possible by forming a local-scale integrated groundwater development system (Groundwater monitoring-Knowledge generation and shearing-Regulatory interventions-Public participation-Institutional responsibility) based on the joint cooperation of the government and the local people. So, this groundwater potential zone (GPZ) maps in the studied area may be helpful for government agencies and policymaker to monitor groundwater and regulate groundwater exploration in the region especially for the development of suitable groundwater for agricultural sectors.

Acknowledgements The authors are thankful to the Indian Space Research Organization (ISRO) especially Bhuvan web portal, United States Geological Survey (USGS), Central Ground Water Board (CGWB), National Bureau of Soil Survey and Land Use Planning (NBSS \& LUP), India, Meteorological Department (IMD), and Geological Survey of India (GSI) for their support during the work. The authors also extend their thanks to anonymous Reviewers for the valuable constructive comments and suggestion.
Funding The authors received no sepecific funding for this work.

Data availability The datasets used and/or analyzed during the current study are available from the corresponding author on reasonable request.

\section{Declarations}

Conflict of interest The authors declare that they have no competing interests.

Ethical approval Not applicable.

Open Access This article is licensed under a Creative Commons Attribution 4.0 International License, which permits use, sharing, adaptation, distribution and reproduction in any medium or format, as long as you give appropriate credit to the original author(s) and the source, provide a link to the Creative Commons licence, and indicate if changes were made. The images or other third party material in this article are included in the article's Creative Commons licence, unless indicated otherwise in a credit line to the material. If material is not included in the article's Creative Commons licence and your intended use is not permitted by statutory regulation or exceeds the permitted use, you will need to obtain permission directly from the copyright holder. To view a copy of this licence, visit http://creativecommons.org/licenses/by/4.0/.

\section{References}

Abijith D, Saravanan S, Singh L, Jennifer JJ, Saranya T, Parthasarathy KSS (2020) GIS-based multi-criteria analysis for identification of potential groundwater recharge zones - a case study from Ponnaniyaru watershed, Tamil Nadu, India. HydroResearch 3:1-14. https://doi.org/10.1016/j.hydres.2020.02.002

Akinlalu AA, Adegbuyiro A, Adiat KAN, Akeredolu BE, Lateef WY (2017) Application of multi-criteria decision analysis in prediction of groundwater resources potential: a case of Oke-Ana, Ilesa area Southwestern, Nigeria. NRIAGJ Astron Geophys 6:184-200. https://doi.org/10.1016/j.nrjag.2017.03.001

Arabameri A, Pradhan B, Pourghasemi HR, Rezaei K (2018) Identification of erosion-prone areas using different multi-criteria decision-making techniques and GIS. Geomatics, Nat Hazards Risk 9(1):1129-1155. https://doi.org/10.1080/19475705.2018.1513084

Arabameri A, Lee S, Tiefenbacher JP, Ngo PTT (2020) Novel ensemble of MCDM-artificial intelligence techniques for groundwaterpotential mapping in arid and semi-arid regions (Iran). Remote Sens 12(3):490. https://doi.org/10.3390/rs12030490

Arefin R (2020) Groundwater potential zone identification using an analytic hierarchy process in Dhaka City, Bangladesh. Environ Earth Sci. https://doi.org/10.1007/s12665-020-09024-0

Barua S, Mukhopadhyay BP, Bera A (2021) Integrated assessment of groundwater potential zone under agricultural dominated areas in the western part of Dakshin Dinajpur district, West Bengal, India. Arab J Geosci 14:1042. https://doi.org/10.1007/ s12517-021-07312-y

Bera A, Mukhopadhyay BP, Barua S (2020) Delineation of groundwater potential zones in Karha river basin, Maharashtra, India, using AHP and geospatial techniques. Arab J Geosci 13:693. https://doi. org/10.1007/s12517-020-05702-2

Bhattacharya S, Das S, Das S, Kalashetty M, Warghat SR (2020) An integrated approach for mapping groundwater potential applying 
geospatial and MIF techniques in the semiarid region. Environ Dev Sustain. https://doi.org/10.1007/s10668-020-00593-5

Bhunia GS (2020) An approach to demarcate groundwater recharge potential zone using geospatial technology. Appl Water Sci 10:138. https://doi.org/10.1007/s13201-020-01231-1

Biswas S, Mukhopadhyay BP, Bera A (2020) Delineating groundwater potential zones of agriculture dominated landscapes using GIS based AHP techniques: a case study from Uttar Dinajpur district. West Bengal Environ Earth Sci 79(12):1-25. https://doi.org/10. 1007/s12665-020-09053-9

CGWB (2019) National compilation on dynamic ground water resources of India, 2017.Central Ground Water Board, Department of Water Resources, RD \& GR. Ministry of Jal Shakti, Government of India, Faridabad, http://cgwb.gov.in/GW-Assessment/ GWRA-2017-National-Compilation.pdf

Chen W, Li Y, Tsangaratos P, Shahabi H, Ilia I, Xue W, Bian H (2020) Groundwater spring potential mapping using artificial intelligence approach based on kernel logistic regression, random forest, and alternating decision tree models. Appl Sci 10(2):425. https://doi.org/10.3390/app10020425

Das N, Mukhopadhyay S (2020) Application of multi-criteria decision making technique for the assessment of groundwater potential zones: a study on Birbhum district, West Bengal, India. Environ Dev Sustain 22:931-955. https://doi.org/10.1007/ s10668-018-0227-7

Das B, Pal SC (2019) Assessment of groundwater recharge and its potential zone identification in groundwater-stressed Goghat-I block of Hugli district, West Bengal, India. Environ Dev Sustain 22:5905-5923. https://doi.org/10.1007/s10668-019-00457-7

Dey S, Shukla UK, Mehrishi P, Mall RK (2021) Appraisal of groundwater potentiality of multilayer alluvial aquifers of the Varuna river basin, India, using two concurrent methods of MCDM. Environ Dev Sustain. https://doi.org/10.1007/ s10668-021-01400-5

Doke A, Pardeshi SD, Das S (2020) Drainage morphometry and groundwater potential mapping: application of geoinformatics with frequency ratio and influencing factor approaches. Environ Earth Sci 79:393. https://doi.org/10.1007/s12665-020-09137-6

Ferozu RM, Jahan CS, Arefin R, Mazumder QH (2018) Groundwater potentiality study in drought prone Barind Tract, NW Bangladesh using remote sensing and GIS. Groundw Sustain Dev 8:205-215. https://doi.org/10.1016/j.gsd.2018.11.006

Guru B, Seshan K, Bera S (2017) Frequency ratio model for groundwater potential mapping and its sustainable management in cold desert. India J King Saud Univ Sci 29(3):333-347. https://doi.org/ 10.1016/j.jksus.2016.08.003

Lee S, Lee CW (2015) Application of decision-treemodel to groundwater productivity-potential mapping. Sustainability 7(10):1341613432. https://doi.org/10.3390/su71013416

Lee S, Hong SM, Jung HS (2018) GIS-based groundwater potential mapping using artificial neural network and support vector machine models: the case of Boryeong city in Korea. Geocarto Int 33(8):847-861. https://doi.org/10.1080/10106049.2017.1303091

Luo D, Wen X, Zhang H, Xu J, Zhang R (2020) An improved FAHP based methodology for groundwater potential zones in Longchuan River basin, Yunnan Province, China. Earth Sci Inform. https:// doi.org/10.1007/s12145-020-00469-2

Magesh NS, Chandrasekar N, Soundranayagam JP (2012a) Delineation of groundwater potential zones in Theni district, Tamil Nadu, using remote sensing. GIS and MIF Techniques Geosci Front 3(2):189-196. https://doi.org/10.1016/j.gsf.2011.10.007

Magesh NS, Chandrasekar N, Soundranayagam JP (2012b) Delineation of groundwater potential zones in Theni district, Tamil Nadu, using remote sensing, GIS and MIF techniques. Geosci Front 3(2):189-196. https://doi.org/10.1016/j.gsf.2011.10.007
Maity DK, Mandal S (2019) Identification of groundwater potential zones of the Kumari river basin, India: an RS \& GIS based semiquantitative approach. Environ Dev Sustain 21:1013-1034. https://doi.org/10.1007/s10668-017-0072-0

Mallick J, Khan RA, Ahmed M, Alqadhi SD, Alsubih M, Falqi I, Hasan MA (2019) Modeling groundwater potential zone in a semi-arid region of aseer using fuzzy-AHP and geoinformation techniques. Water 11(12):2656. https://doi.org/10.3390/w11122656

Manap MA, Sulaiman WNA, Ramli MF, Pradhan B, Surip N (2011) A knowledge-driven GIS modeling technique for groundwater potential mapping at the Upper Langat Basin, Malaysia. Arab J Geosci 6(5):1621-1637. https://doi.org/10.1007/s12517-011-0469-2

Mogaji KA, Lim HS, Abdullah K (2015) Regional prediction of groundwater potential mapping in a multifaceted geology terrain using GIS-based Dempster-Shafer model. Arab J Geosci 8(5):3235-3258. https://doi.org/10.1007/s12517-014-1391-1

Mukherjee I, Singh UK (2020) Delineation of groundwater potential zones in a drought-prone semi-arid region of east India using GIS and analytical hierarchical process techniques. CATENA 194:104681. https://doi.org/10.1016/j.catena.2020.104681

Naghibi SA, Pourghasemi HR (2015) Acomparative assessment between three machine learning models and their performance comparison by bivariate and multivariate statistical methods in groundwater potential mapping. Water Resour Manag 29(14):5217-5236. https://doi.org/10.1007/s11269-015-1114-8

Nithya CN, Srinivas Y, Magesh NS, Kaliraj S (2019) Assessment of groundwater potential zones in Chittar basin, Southern India using GIS based AHP technique. Remote Sens Appl Soc Environ 15:100248. https://doi.org/10.1016/j.rsase.2019.100248

Owolabi ST, Madi K, Kalumba AM, Orimoloye IR (2020) A groundwater potential zone mapping approach for semi-arid environments using remote sensing (RS), geographic information system (GIS) and analytical hierarchical process (AHP) techniques: a case study of Buffalo catchment, Eastern Cape, South Africa. Arab J Geosci. https://doi.org/10.1007/s12517-020-06166-0

Pande CB, Moharir KN, Singh SK, Varade AM (2019) An integrated approach to delineate the groundwater potential zones in Devdari watershed area of Akola district, Maharashtra, Central India. Environ Dev Sustain 22:1-21. https://doi.org/10.1007/ s10668-019-00409-1

Parameswari K, Padmini TK (2018) Assessment of groundwater potential in Tirukalukundram block of southern Chennai Metropolitan Area. Environ Dev Sustain 20:1535-1552. https://doi.org/10. 1007/s10668-017-9952-6

Patra S, Mishra P, Mahapatra SC (2018) Delineation of groundwater potential zone for sustainable development: a case study from Ganga Alluvial Plain covering Hooghly district of India using remote sensing, geographic information system and analytic hierarchy process. J Clean Prod 172:2485-2502. https://doi.org/10. 1016/j.jclepro.2017.11.161

Pourtaghi ZS, Pourghasemi HR (2014) GIS-based groundwater spring potential assessment and mapping in the Birjand Township, southern Khorasan Province. Iran Hydrogeol J 22(3):643-662. https:// doi.org/10.1007/s10040-013-1089-6

Rahmati O, Pourghasemi HR, Melesse AM (2016) Application of GISbased data driven random forest and maximum entropy models for groundwater potential mapping: a case study at Mehran Region Iran. CATENA 137:360-372. https://doi.org/10.1016/j.catena. 2015.10.010

Rajasekhar M, Sudarsana RG, Siddi RR (2019) Assessment of groundwater potential zones in parts of the semi-arid region of Anantapur District, Andhra Pradesh, India using GIS and AHP approach. Model Earth Syst Environ 5:1303-1317. https://doi.org/10.1007/ s40808-019-00657-0

Raju RS, Raju GS, Rajasekhar M (2019) Identification of groundwater potential zones in Mandavi river basin, Andhra Pradesh, India 
using remote sensing GIS and MIF techniques. HydroResearch 2:1-11. https://doi.org/10.1016/j.hydres.2019.09.001

Razandi Y, Pourghasemi HR, Neisani NS, Rahmati O (2015) Application of analytical hierarchy process, frequency ratio, and certainty factor models for groundwater potential mapping using GIS. Earth Sci Inf 8(4):867-883. https://doi.org/10.1007/s12145-015-0220-8

Rudra K, Mukherjee SS, Mukhopadhyay UK, Gupta D (2017) State of environment report, West Bengal, 2016. Saraswaty Press Ltd, West Bengal Pollution Control Board

Saaty TL (1980) The analytic hierarchy process. McGraw-Hill, New York

Saaty TL (1990) How to make a decision: the analytic hierarchy process. Eur J Oper Res 48(1):9-26. https://doi.org/10.1016/03772217(90)90057-I

Saha D, Dhar YR, Vittala SS (2010) Delineation of groundwater development potential zones in parts of marginal Ganga Alluvial Plain in South Bihar, Eastern India. Environ Monit Assess 165(1):179_ 191. https://doi.org/10.1007/s10661-009-0937-2

Saha D, Talukdar D, Senapati U, Das TK (2021) Exploring vulnerability of groundwater using AHP and GIS techniques: A study in Cooch Behar District, West Bengal, India. In: Shit P.K., Bhunia G.S., Adhikary P.P., Dash C.J. (eds) Groundwater and society. Cham: Springer. https://doi.org/10.1007/978-3-030-64136-8_21

Senapati U, Das TK (2020) Assessment of potential land degradation in Akarsha Watershed, using GIS and multi-influencing factor technique. In: Shit P., Pourghasemi H., Bhunia G. (eds) Gully erosion studies from India and surrounding regions. Advances in Science, Technology \& Innovation (IEREK Interdisciplinary Series for Sustainable Development). Cham: Springer, pp 187-205. https:// doi.org/10.1007/978-3-030-23243-6_11

Senapati U, Das TK (2021) Assessment of basin-scale groundwater potentiality mapping in drought-prone upper Dwarakeshwar River basin, West Bengal, India, using GIS-based AHP techniques. Arab J Geosci 14(11):1-22. https://doi.org/10.1007/ s12517-021-07316-8

Senapati U, Raha S, Das TK, Gayen SK (2021) A composite assessment of agricultural drought susceptibility using analytic hierarchy process: case study of western region of West Bengal. In: Rukhsana, Alam A. (eds) Agriculture, food and nutrition security. Cham: Springer. https://doi.org/10.1007/978-3-030-69333-6_2

Serele C, Pérez-Hoyos A, Kayitakire F (2019) Mapping of groundwater potential zones in the drought-prone areas of south Madagascar using geospatial techniques. Geosci Front. https://doi.org/10. 1016/j.gsf.2019.11.012
Shao Z, Huq ME, Cai B, Altan O, Li Y (2020) Integrated remote sensing and gis approach using fuzzy-AHP to delineate and identify groundwater potential zones in Semi-Arid Shanxi Province, China. Environ Model Softw Environ Modell Softw. https://doi. org/10.1016/j.envsoft.2020.104868

Shekhar S, Pandey AC (2015) Delineation of groundwater potential zone in hard rock terrain of India using remote sensing, geographical information system (GIS) and analytic hierarchy process (AHP) techniques. Geocarto Int 30(4):402-421. https://doi.org/10. 1080/10106049.2014.894584

Shen Y, Oki T, Kanae S, Hanasaki N, Utsumi N, Kiguchi M (2014) Projection of future world water resources under SRES scenarios:an integrated assessment. Hydrol Sci J 59(10):1775-1793. https:// doi.org/10.1080/02626667.2013.862338

Taylor RG, Scanlon B, Döll P, Rodell M, Van Beek R, Wada Y et al (2012) Ground water and climate change. Nat Clim Chang 3:322329. https://doi.org/10.1038/nclimate 1744

Thapa R, Gupta S, Guin S, Kaur H (2017) Assessment of groundwater potential zones usingmulti-influencing factor (MIF) and GIS: a case study from Birbhum district. West Bengal Appl Water Sci 7(7):4117-4131. https://doi.org/10.1007/s13201-017-0571-z

Tucker CJ (1979) Red and photographic infrared linear combinations for monitoring vegetation. Remote Sens Environ 8(2):127-150. https://doi.org/10.1016/0034-4257(79)90013-0

Yeh HF, Cheng YS, Lin HI, Lee CH (2016) Mapping groundwater recharge potential zone using a GIS approach in Hualian River. Taiwan Sustain Environ Res 26:33-43. https://doi.org/10.1016/j. serj.2015.09.005

Zabihi M, Pourghasemi HR, Pourtaghi ZS, Behzadfar M (2016) GISbased multivariate adaptive regression spline and random forest models for groundwater potential mapping in Iran. Environ Earth Sci 75(8):665. https://doi.org/10.1007/s12665-016-5424-9

Zghibi A, Mirchi A, Msaddek MH, Merzougui A, Zouhri L, Taupin JD, Chekirbane A, Chenini I, Tarhouni J (2020) Using analytical hierarchy process and multi-influencing factors to map groundwater recharge zones in a semi-arid mediterranean coastal aquifer. Water 12(9):2525. https://doi.org/10.3390/w12092525

Publisher's Note Springer Nature remains neutral with regard to jurisdictional claims in published maps and institutional affiliations. 